\title{
THE SEED OF THE WOMAN AND THE BLESSING OF ABRAHAM
}

\author{
James Hamilton
}

\begin{abstract}
Summary
Might the blessing of Abraham in Genesis 12:1-3 be a direct answer to the curses of Genesis 3:14-19? The curses of Genesis 3 introduce conflict between the seed of the serpent and the seed of the woman, conflict between the man and the woman, with difficulty in childbearing, and conflict between the man and the ground, which is cursed for man's sin. God promises land, seed, and blessing to Abraham. The nations will be blessed through the seed of the woman, seed of Abraham, who crushes the serpent's head. The birth of this seed means that the conflict between the man and his wife is not final, nor will the difficulty in childbearing be fatal. And God promises land to Abraham and his seed, land that hints of a return to Eden.
\end{abstract}

'For if you believed Moses, you would believe me; for he wrote about me.' -Jesus of Nazareth (John 5:46)

\section{Introduction}

Many discussions rightly see the importance of the promises God makes to Abraham in Genesis 12:1-3. One sometimes gets the impression that Genesis 1-11 is regarded as a shadowy prehistoric prelude to the real story of the history of Israel that finally begins in Genesis 12. On the other hand, David Clines affirms that the promise to Abraham represents 'an affirmation of the primal divine intentions for humanity', ${ }^{1}$ but is it possible to be more specific? Is it possible that

1 D. J. A. Clines, The Theme of the Pentateuch (2nd edn; Sheffield: JSOT, 1997): 30 (italics removed). 
there is a more intimate connection between Genesis 1-11 and Genesis 12 and following? More specifically, could it be that the promises and blessings given to Abraham in Genesis 12:1-3 are direct answers to the curses of Genesis 3:14-19? ${ }^{2}$ If this is the case, given the influence of the blessing of Abraham in Genesis 12:1-3 on the rest of the Bible, might it be that the curses of Genesis 3 , and particularly the curse on the serpent in 3:15, exercise similar influence on the rest of the Bible? ${ }^{3}$ This study will first consider the possible connections between the curses of Genesis 3 and the blessings of Genesis 12. From there we will consider the way Genesis 3:15 might be interpreted in the rest of the Bible.

\section{Curses Answered by Blessings: Is Genesis 12 the Antidote of Genesis 3?}

Before taking up the question of the relationship between Genesis 3 and 12 directly, a few brief observations about Genesis 1-11 are necessary. We first observe the oft noted regal nature of Adam's commission and role (Gen. 1:26-28). ${ }^{4}$ Our first father Adam is a royal figure with a priestly role. As the priests would work and keep the tabernacle and temple, Adam is to work and keep the garden. ${ }^{5}$ From the beginning, then, Adamic kingship has a priestly cast.

2 Having come to this view independently, I found this statement by W. Brueggemann (Theology of the Old Testament [Minneapolis: Fortress, 1997]: 498): 'Hans Walter Wolff and a host of scholars after him have seen that the summons and mandate to Abraham (and Sarah) in Gen 12:1-3 is situated as the antidote to the sorry state of the nations in Genesis 3-11. Thus the nations are under curse (cf. Gen. 3:14$19 ; 4: 11-12 ; 9: 25)$, and now Israel is presented as the agent and instrument of Yahweh in the world, to bring a blessing to the world of curse.' Brueggemann cites Wolff, 'The Kerygma of the Yahwist', Int 20 (1966): 131-58 and others. Brueggemann does not pursue this insight in the direction I follow it here.

3 I have argued that the curse on the serpent in Genesis 3:15 does, in fact, resonate through the rest of the OT and into the New in 'The Skull Crushing Seed of the Woman: Inner-Biblical Interpretation of Genesis 3:15', SBJT 10.2 (2006): 30-54.

4 See, for example, G. K. Beale, The Temple and the Church's Mission: A Biblical Theology of the Dwelling Place of God (Downers Grove: InterVarsity, 2004): 70; W. J. Dumbrell, The Faith of Israel (2nd edn; Grand Rapids: Baker, 2002): 17; J. Goldingay, Old Testament Theology: Israel's Gospel (Downers Grove: InterVarsity, 2003): 99100.

5 G. J. Wenham observes 'that the only other passages in the Pentateuch where these

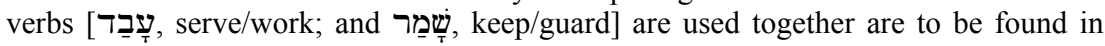
Num. 3:7-8; 8:26; 18:5-6, of the Levites' duties in guarding and ministering in the sanctuary. If Eden is seen then as an ideal sanctuary, then perhaps Adam should be 
Greg Beale has offered the stimulating proposal that the task of working and keeping the garden (2:15) entails extending its borders so that all the land will be habitable for YHWH. ${ }^{6}$ This will result in the glory of YHWH covering all the earth as the waters cover the sea (Num. 14:21).

Once the exile from the garden has been narrated (Gen. 3), a ten member genealogy carefully traces the line of descent from Adam to Noah (5:1-32), and then another ten member genealogy traces the line of descent from Noah's son Shem to Abram (11:10-26). ${ }^{7}$ These genealogies establish an important connection between Adam and Abraham. $^{8}$

\subsection{The Curses}

The curses of Genesis 3:14-19 can be broadly summarised under three headings. God first addressed the serpent, then the woman, and finally the man. God tells the serpent he will be more cursed than all other animals, which seems to be explained by the statements that he will now move on his belly and eat dust (3:14). Genesis $3: 15$ then introduces enmity between the serpent and the woman and between the seed of the serpent and the seed of the woman. The final clause of Genesis 3:15 states that the seed of the woman will crush the serpent's head, while the serpent will crush the heel of the seed of the woman. The term 'seed' is a collective singular, meaning that it always appears in the singular whether it has a plural or a singular referent. We will return to the use of the term 'seed' below.

Rather than being cursed directly, the man and the woman have their roles made more difficult. ${ }^{9}$ The woman was to help the man (2:18), and

described as an archetypal Levite' ('Sanctuary Symbolism in the Garden of Eden Story' in I Studied Inscriptions from before the Flood, ed. R. S. Hess and D. T. Tsumura [Winona Lake: Eisenbrauns, 1994]: 401).

6 Beale, Temple, 81-87.

7 T. D. Alexander, 'From Adam to Judah: The Significance of the Family Tree in Genesis', EvQ 61 (1989): 5-19; S. G. Dempster, Dominion and Dynasty: A Theology of the Hebrew Bible (Downers Grove: InterVarsity, 2003): 68-72, 75.

8 We might also note the connection between Abraham and Adam made by the transmission of Adam's commission to 'be fruitful and multiply' (1:28), which is passed on to Noah $(9: 1,7)$. Abram is then promised that God will multiply him (12:2; 17:6a; 22:17). Isaac commissions Jacob to be fruitful and multiply (28:3), and God too gives this commission to Jacob $(35: 11 ; 48: 3-4)$. When Israel goes to Egypt, they are fruitful and multiply (47:27).

9 G. J. Wenham, Genesis 1-15 (Waco: Word, 1987): 81; J. H. Sailhamer, Genesis (Grand Rapids: Zondervan, 1990): 56-57. 
together they were to be fruitful and multiply $(1: 28)$. They will be able to multiply, and the seed of the woman will crush the serpent's head (3:15), but God promises to make the bearing of seed painful for the woman (3:16). Secondly, the conception of the triumphant seed will be difficult not only because of increased pain but because the 'one flesh' harmony (2:23-25) enjoyed before the transgression (3:1-6) has been polluted by fear and shame (3:7-13). The woman will have a new desire to usurp her husband's authority, and the man will relate to the woman with a new brutality: 'Your desire will be for your husband, and he shall rule over you' $(3: 16){ }^{10}$ The seed of the woman will crush the serpent's head, but for the seed to be born, relational and physical barriers must be overcome.

The man's role was to work the garden and keep it (2:15), and his role is made more difficult by the curse on the ground ('Cursed is the ground because of you,' $3: 17$ ). No longer will Adam work the blessed land of Eden. Now his sweaty labour will be painful, and the ground will yield thorns and thistles. Dust he is and to dust he shall return (3:17-19). The loss of Eden land becomes explicit in 3:23, where the narrative states that the man was 'sent out from the garden to work the ground from which he was taken'.

We can group these curses according to their relational results under three headings: (1) conflict between the seed of the serpent and the seed of the woman; (2) conflict between the woman and the man; and (3) conflict between the man and the ground.

The command not to eat of the tree carried with it the threat of death, and in addition to the allusion to the man's eventual death in $3: 17-19$, the couple is sent out from the realm of life, where God dwells, when they are expelled from Eden. ${ }^{11}$ But while the curses on the man and the woman introduce difficulty and dying, the only statement of ultimate defeat in the curses of 3:14-19 is in the promise to

\footnotetext{
10 The interpretation of this statement is sometimes misunderstood. I am following Tremper Longman III, How to Read Genesis (Downers Grove: InterVarsity, 2005): 113, Sailhamer (Genesis, 56-58), and Wenham (Genesis 1-15, 81-82). All note the use of the word תק in in Gen. 4:7; and I think its use in Song 7:10 is pointing to a reversal of the curse (see James M. Hamilton Jr, 'The Messianic Music of the Song of Songs: A Non-Allegorical Interpretation', WTJ 68 [2006]: 331-45).

11 Wenham (Genesis 1-15,90) writes, 'Like the garden of Eden, the tabernacle was a place where God walked with his people. To be expelled from the camp of Israel or to be rejected by God was to experience a living death.... The expulsion from the garden of delight where God himself lived would therefore have been regarded by the godly men of ancient Israel as yet more catastrophic than physical death.'
} 
the serpent that the seed of the woman would crush his head in 3:15. Old Testament theologians from Gerhard von Rad to Stephen Dempster have seen Adam's naming of Eve as an act of faith. ${ }^{12}$ Adam hears that his wife will bear a child who will crush the serpent's head, which means that the sentence of death is not going to be enacted immediately, thus she can be named Eve. The Hebrew form of the name Eve (חָ) in close to the word for 'living' (חיריה

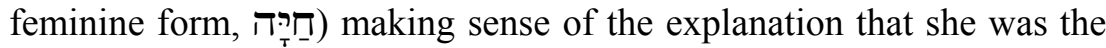
mother of all living (3:20).

Eve's statement at the birth of Cain, 'I have gotten a man with YHWH' (4:1) seems to indicate that she is looking for the birth of the seed who will crush the serpent's head. ${ }^{13}$ This possibility is strengthened by the correspondence in vocabulary between Genesis $4: 1$ and 3:16. The term for 'conception/pregnancy' in 3:16, הרוֹן, appears to be related to the verb 'conceived', הרה, in 4:1, and the verb for bearing children, ילד, is the same in both verses.

It turns out that Cain not only fails to crush the serpent's head, he kills the other seed of the woman who might have done so (Gen. 4:8). Later Jewish interpreters treat Cain as a seed of the serpent (see esp. John 8:44; 1 John 3:8-12). ${ }^{14}$ The conflict between Cain and Abel looks like an outworking of the enmity between the seed of the serpent and the seed of the woman promised in Genesis 3:15. ${ }^{15}$ When next Adam and Eve produce a child, Eve indicates that she is still looking for her seed who will crush the serpent's head: 'God has given me another seed in place of Abel, since Cain killed him' (Gen. 4:25). ${ }^{16}$

12 Gerhard von Rad, Genesis: A Commentary (Philadelphia: Fortress, 1976): 96; Dempster, Dominion and Dynasty, 68.

13 Sailhamer, Genesis, 60.

14 Apocalypse of Abraham 24:5 indicates that Cain slew Abel under the influence of the adversary, who is described in 23:7 as a dragon. There appear to have been Jewish traditions that Eve had intercourse with Satan and that Cain was the 'son of Satan'. See the references in Louis Ginsberg, The Legends of the Jews: From the Creation to the Exodus: Notes for Volumes 1 and 2, vol. 5 (repr., Johns Hopkins, 1998): 133-34 n. 3. This interpretation finds attestation in Christian tradition in the heroic poem, Beowulf, slayer of the demonic monsters Grendel and his mother, who belong to the family of Cain. Beowulf later dies slaying a dragon as his twelve companions flee. Relish Seamus Heaney's, Beowulf: A New Verse Translation (New York: Norton, 2000).

15 Cf. H. W. Wolff, 'The Kerygma of the Yahwist', 145: 'After the curse has first been brought to bear on the Serpent and the Garden, it falls on Cain and Canaan, illustrative of men who are fathers of nations.'

16 So also Dempster, Dominion and Dynasty, 71; Sailhamer, Genesis, 68-69. 
Near the end of the genealogy in Genesis 5, the deadly rhythm is interrupted by a significant comment at the birth of Noah. His father Lamech utters a statement that recalls the curse of $3: 17$. We read in Genesis 5:28-29, 'And Lamech lived 182 years and he fathered a son. And he called his name Noah, saying, "this one will give us rest from our work and from the pain of our hands from the ground which YHWH cursed." Terms used in both Genesis 3:17 and 5:29 include

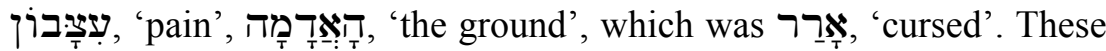
words depict a hope for an end of the curse and perhaps a return to Edenic conditions. ${ }^{17}$ This hope, moreover, is expressed at the birth of a child born to a line that is meticulously traced back to Adam. Could this indicate that when the seed of the woman crushes the serpent's head, the curse on the ground might be lifted? Moving forward, might it be that the nature of what God will do to overcome the curse of sin is clarified by what God promises to Abraham in Genesis 12 ?

\subsection{The Blessings}

I am suggesting that the curses of Genesis 3 are confronted head-on once the genealogies of Genesis 5 and 11 have traced the descent of the seed of the woman down to Abram. In Genesis 12:1 Abram is commanded to go to the land that YHWH will show him. Then in 12:2 God promises Abram that he will make him a great nation, bless him, and make his name great. In 12:3 God promises to bless those who bless Abram and curse those who dishonour him, concluding with the statement that all the families of the earth will be blessed in Abram. T. Desmond Alexander has summarised the blessings of Abraham as pertaining to seed, land, and blessing. ${ }^{18}$

Genesis 11:30 informs the reader that Sarai was barren, but for the promise in 12:2 that Abram will become a great nation to be realised, children will have to be born. It eventually becomes clear that God intends to reverse Sarai's barrenness (17:15-21). Prior to this, however, Sarai's barrenness provides an occasion for the curse in 3:16 to be worked out as she takes the initiative regarding what the family should do by telling Abram to go in to Hagar (16:1-4). Abram complies with

17 Dempster, Dominion and Dynasty, 71; C. F. Keil, The Pentateuch (Commentary on the Old Testament by C. F. Keil and F. Delitzsch; Peabody: Hendrickson, 2001 [186691]): 1:80; John Calvin, Genesis (Grand Rapids: Baker, 1979 [1554]): 1:233-34.

18 T. Desmond Alexander, From Paradise to the Promised Land (Grand Rapids: Baker, 1995): 48-50. 
his wife's desires, but this leads only to more conflict between himself and Sarai (16:5-6). ${ }^{19}$ The promise that Abram will become a great nation is a promise that the curses of Genesis 3:16 - that the woman will have pain and that she will desire her husband but he will rule over her - will be overcome.

The command for Abram to go to the land he will be shown and the promise that he will be made a great nation (12:1-2) imply that land will be given, and this becomes explicit in 12:7 when YHWH promises to give the land to Abram's seed. This promised land relates to the curse on the ground in Genesis 3:17-19, which signalled the loss of Eden (cf. 3:23). ${ }^{20}$ The loss of Eden means exile from God's presence, but God later renews his dwelling among Israel by taking up residence in the Tabernacle. Once the people enter the land, God will dwell in a Temple. In the New Creation, the dwelling of God will be with men (Rev. 21:3). So when we consider God's presence, there appears to be a trajectory from Eden to Tabernacle to Land and Temple to New Creation. ${ }^{21}$

There are indications in the Pentateuch that the camp of Israel, with the Tabernacle at its heart, recaptures something of what was lost when Adam and Eve were exiled from Eden. Israel's camp is likened to a garden YHWH planted in Numbers 24:5-6. What the camp of Israel anticipates is also the goal of the conquest of the land. The camp and later the land correspond to Eden in that they are places wherein God will 'walk among' his people (cf. Gen. 3:8; Lev. 26:11-13; Deut. 23:14). Eden, the Tabernacle, and the Temple are all entered from the east

19 For other examples in Genesis that seem to point back to the 'gender conflict' introduced in 3:16, see the episode in Sodom, a city with its own gender issues, where Lot is ready to offer his virgin daughters to a rapacious crowd (19:8). Then the tragic distortion of the father-daughter relationship at the end of the chapter surely reflects the loss of Edenic innocence (19:30-38). Rebekah takes charge of whom Isaac will bless (27:5-13). Jacob's two wives are hardly in harmony, resulting in Jacob being angry with Rachel (30:1-2). The rape of Dinah points to an utter failure of manhood, man ruling over woman in gross brutality (34:1-2). The incidents between Tamar and Onan (38:9), Tamar and Judah (38:12-26), and Potiphar's wife with Joseph (39:11-18) might also be seen as reverberations of Genesis 3:16. Other examples of gender conflict could be cited, but these are sufficient to make the point that Genesis seems to give many examples of the outworking of the curse in Genesis 3:16.

20 For the outworkings of the curse on the land in Genesis, see, for example, the famines in $12: 10 ; 26: 1$; and $41: 54$.

21 See James M. Hamilton Jr, 'God with Men in the Torah', WTJ 65 (2003): 113-33; 'God with Men in the Prophets and the Writings: An Examination of the Nature of God's Presence', SBET 23.2 (2005) 166-93; and God's Indwelling Presence: The Holy Spirit in the Old and New Testaments (Nashville: Broadman \& Holman, 2006). 
(Gen. 3:24). The way to Eden is guarded by cherubim (Gen. 3:24), and cherubim guard the ark in the holy of holies (Exod. 25:10-22) and adorn the walls of both Tabernacle and Temple (Exod. 26:1; $1 \mathrm{Kgs}$ 7:29). The lampstand in the Tabernacle and the Temple corresponds to a sacred tree, reminiscent of Eden, and there are other points of contact. $^{22}$ By promising land to Abram, YHWH seems to be addressing both the curse on the ground (3:17-19) and the expulsion from Eden $(3: 23)$.

So the conflict between the man and the land introduced in Genesis 3:17-19 is addressed by the promise to Abram that the land will be given to his seed in 12:7 (cf. 12:1-2). In the broader biblical theological context, this promise has overtones of a restoration of Edenic conditions. The conflict between the woman and the man introduced in Genesis 3:16 is likewise addressed in the promise to Abram that he will be a great nation in 12:2, which points to the eventual overcoming of the physical and relational barriers to fertility that he and Sarai face.

The third aspect of the promises made to Abram is concerned with the blessing of those who bless Abram and the cursing of those who curse him, as well as the promise that all families of the earth will be blessed in him (12:3). The last part of this promise, that of the nations being blessed in Abram, is later extended to Abram's seed (18:18; $22: 18 ; 26: 4 ; 28: 14)$. How might the nations be blessed through Abram and his seed? One possibility is that the overcoming of the curses of Genesis 3 and the opening of the way to Eden would portend weal for all people. The crushing of the serpent's head, promised in Genesis $3: 15$, could point to the ultimate victory of the collective and singular seed of the woman over the serpent and his seed. The blessing of those who bless Abram might point to a widening of the collective seed of the woman. Not only those who are physical descendants of Abram will be blessed. The cursing of those who dishonour Abram spells disaster for the seed of the serpent. ${ }^{23}$ The blessing of all the families of

22 I owe these insights to Gordon Wenham and Greg Beale, whose writings can be consulted for further information: Wenham, 'Sanctuary Symbolism in the Garden of Eden Story' in I Studied Inscriptions from before the Flood, 399-404; Beale, Temple, 66-99.

23 For conflict between the seed of the woman and the seed of the serpent in Genesis, see the examples of individual enmity between the seeds of the woman and the serpent in the lives of Abel and Cain (4:8), Isaac and Ishmael (21:9), Jacob and Esau (27:42), and Joseph and his brothers (37:4). Examples of enmity between the seeds at a corporate level may be seen in the accounts of Abraham and Abimelech's servants (21:25), Isaac and the Philistines (26:14-16), the Shechemites (ch. 34) and cf. 4:23-24 
the earth through Abram and his seed $(12: 3 ; 22: 18)$ directs readers of the Genesis narrative to a seed of the woman who will crush the serpent's head, repeal the curses, and open the way to Eden. Abraham, renamed in Genesis 17:5, is also promised that he will sire kings in 17:6, and this hearkens back to Adam's original royal status. These observations substantiate the views expressed by von Rad when he wrote,

The pre-patriarchal history [Gen. 1-11] keys in with the history of redemption: Abraham is called out of all the nations and he is promised the blessing 'that all the races on earth will be blessed in him'... The pre-patriarchal history, ending on a note of despair in the Tower story, is inseparably bound up with the opening of the redemptive history with its promise of a blessing for Israel and, through Israel, for 'all the races on earth.' 24

\section{All Nations Blessed in the Seed of the Woman?}

If what I am suggesting is correct, we might expect to find passages that set the fulfilment of the promises made to Abraham next to the judgement on the serpent that his head would be crushed. Before taking up the issue of whether or not this happens, however, some comments on 'seed' and the blessing of Abraham are in order.

\subsection{Seed}

First, we must note the significance of the term 'seed' in Genesis, along with the tension created by the fact that it can refer to a singular seed or a collective seed. This is most easily illustrated from the ESV's translation of Genesis 22:17-18. The ESV renders verse 17a as follows, 'I will surely bless you, and I will surely multiply your offspring [seed] as the stars of heaven and as the sand that is on the seashore'. Here the Hebrew term זִרעי, seed, clearly refers to a multitude of descendants even though it is in the singular. In Genesis 22:17b-18a, however, apparently because of the singular verbs and pronominal suffixes,

and 10:8-12. For the blessing of those who bless Abraham and his seed in Genesis, see Melchizedek blessing Abram (14:19), Abimelech's recognition that God is with Abraham (21:22), a similar instance with Isaac (26:28), Laban's recognition that he has been blessed because of Jacob (30:27), and Egypt and the world being blessed because of Joseph (41:56-57; 50:20).

24 Gerhard von Rad, The Problem of the Hexateuch and Other Essays, tr. E. W. Trueman Dicken (Edinburgh and London: Oliver and Boyd, 1966): 65. 
which Collins and Alexander have argued point to a singular seed, ${ }^{25}$ the ESV switches from a collective understanding of the seed to a singular: 'And your offspring [seed] shall possess the gate of his ${ }^{26}$ enemies, and in your offspring [seed] shall all the nations of the earth be blessed' (emphasis and bracketed notes added). ${ }^{27}$ This corresponds to what $\mathrm{H}$. Wheeler Robinson described as 'the fluidity of reference, facilitating rapid and unmarked transitions from the one to the many, and from the many to the one'. ${ }^{28}$ And this tension between the singular and the plural was evidently noticed by Paul, who in Romans 16:20 applies a 'seed' text to the collective congregation of Christians, under whose feet he tells them God will soon crush Satan. In Galatians 3:16, however, Paul insists on the singularity of the 'seed' before showing how the promises to the singular seed come to the collective seed through baptism into Messiah in 3:27-29. Thus, we should not be surprised that both 'seed of the serpent' and 'seed of the woman' can refer to multiple or singular 'seeds'.

\subsection{Blessing}

We must also note that the promises made to Abraham are passed on to his seed, and as the narrative unfolds these promises are clarified. What has been promised comes into sharper focus as the original blessings are restated with new promises layered onto the old ones. Genesis 12:3 states, 'and all the families of the earth shall be blessed in you'. This promise is restated in Genesis 18:18, and in 22:18a it is passed on to Isaac, 'And all the nations of the earth shall be blessed in your seed' (cf. 21:12). Isaac, too, is told that in his seed all the nations of the earth will be blessed, which passes the promise on to Jacob (26:4). Like Abraham, Isaac is told that the land will be given to his seed, and YHWH promises to establish for him what was sworn to Abraham (26:3). Isaac then blesses Jacob (27:26-29, cf. 27:29c and 12:3a), and

25 Jack Collins, 'A Syntactical Note (Genesis 3:15): Is the Woman's Seed Singular or Plural?' TynBul 48 (1997): 139-48; T. D. Alexander, 'Further Observations on the Term "Seed" in Genesis', TynBul 48 (1997): 363-67.

26 The KJV also has the singular, while the NAB, NAS, NIV, and NKJV opt for the plural, 'their'.

27 Inexplicably, the ESV reverts to the plural in Gen. 24:60 ('and may your offspring possess the gate of those who hate them!') even though it is almost identical to 22:1718 (see Alexander, 'Further Observations').

28 H. W. Robinson, Corporate Personality in Ancient Israel (rev. edn; Philadelphia: Fortress, 1964 [1936-37]): 27. 
confers to him and his seed 'the blessing of Abraham' (28:3-4). It seems from the narrative that Joseph will be next in line as the recipient of the blessing of Abraham, especially with the pregnant statement in Jacob's blessing on Joseph: 'from there is the shepherd, the stone of Israel' (49:24). A significant statement is also made to Judah (49:9-12), however, recalling the promise that kings would come from Abraham $(17: 6) .{ }^{29}$ The statement that 'the sceptre will not depart from Judah ...' (49:10) indicates that Judah's will be the royal line. ${ }^{30}$

\subsection{Overcoming Curses with Blessings}

We are now ready to return to the issue of whether we find Genesis $3: 15$ set next to $12: 1-3$. We will explore one passage from the Pentateuch, one from the historical writings, one from the Psalms, and then we will compare what we find with several statements made in the NT.

The blessings of Abraham are prominent in the Balaam oracles of Numbers 22-24. Balak summons Balaam to curse Israel (Num. 22:6, 17), but God tells Balaam that he cannot curse Israel because Israel is blessed (22:12). Balaam then exclaims, 'How can I curse whom God has not cursed, and how can I denounce whom YHWH has not denounced?' (23:8). ${ }^{31}$ When Balaam declares that God is not a man and so will neither lie nor change his mind but will keep his promise (23:19), readers of the story of the Pentateuch are reminded of God's promise to bless Abraham and his descendants. The likelihood that Genesis 12 might be in view is perhaps strengthened by the words in Numbers 23:24, which are very reminiscent of Genesis 49:9. After a reference to Israel's king in Numbers 24:7, two texts from Genesis are brought together in Numbers $24: 9 .{ }^{32}$ Genesis $49: 9 \mathrm{~b}$ is quoted almost

29 Sailhamer ('Creation, Genesis 1-11, and the Canon', BBR 10 [2000]: 96 n. 28) writes, 'the Judah material more likely reflects the primary interest of the writer. There are, in fact, several instances throughout Genesis 37-50 where material relating to Judah has been intentionally inserted into the story of Joseph.'

30 Cf. T. Jud. 1:6, "my father declared to me, "You shall be king, achieving success in every way."' See also Gen. 17:6.

31 Paul House (Old Testament Theology [Downers Grove: InterVarsity, 1998]: 164) sees the Abrahamic covenant stressed in Numbers 23:7-10. Other points of contact between the blessing of Abraham and Balaam's oracles include the indication that Israel cannot be numbered in Num. 23:10, recalling Gen. 13:16. There is a heavy emphasis throughout on blessing and cursing: Num. 23:11, 13, 20, 25-27; 24:10.

32 J. Sailhamer, 'Creation, Genesis 1-11, and the Canon', 93. 
verbatim in Numbers 24:9a (one word is different, and the pointing of another is slightly varied).

Genesis 49:9b

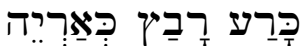

He stooped, he crouched as a lion

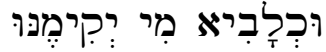

And as a lion

who will cause him to rise?
Numbers 24:9a

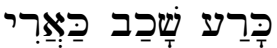

He stooped, he lay as a lion

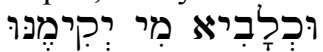

And as a lion

who will cause him to rise?

And then Numbers 24:9b is reminiscent of Genesis 12:3a, repeating the words of Genesis $27: 29 \mathrm{c}$ but putting the blessing before the cursing.

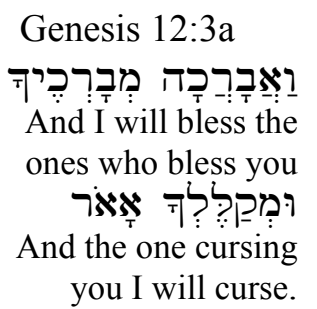

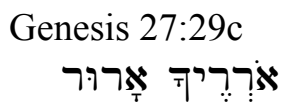

The ones cursing you will be cursed

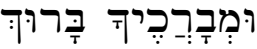
And the ones blessing you will be
Numbers 24:9b

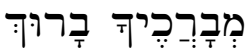

The ones blessing you will be blessed

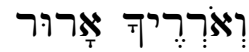

And the ones cursing you will be cursed.

The placement of the allusion to the ruler from the line of Judah (Num. 24:9a) next to the allusion to the blessing of Abraham (24:9b) interweaves these lines of promise. If it was not clear before Numbers 24:9 that these promises belong together, this verse sounds the note that unites the themes. This union means that the blessing of Abraham will come through the king who will arise from the line of Judah, reminding readers of the Pentateuch of the promise to Abraham that he would sire kings (Gen. 17:6; see the references to Israel's king in Num. 23:21; 24:7). Balaam's oracles, then, clarify the blessing of Abraham by linking it to the king from Judah. But do Balaam's oracles include any reference to material that comes before the blessing of Abraham material from Genesis 2-3?

Numbers 24:6 has been noted above. There the tents of Jacob, the encampments of Israel (24:5), are likened to 'gardens beside a river, like aloes planted by YHWH'. This hearkens back to Genesis 2:8-10. In

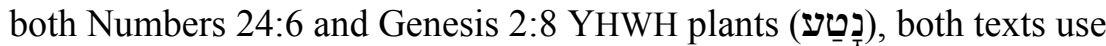

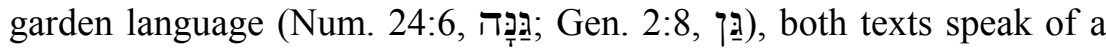
river (נָָד points to something Edenic about the camp of Israel, and this is followed by a reference to a triumphant king to whom God gives 
victory (24:7-8). Then follows the recapitulation of Genesis 12:3, 27:29, and 49:9 in Numbers 24:9. The person in view in Numbers 24:9 is the exalted king mentioned in 24:7-8. Thus, hard on the heels of the allusions to Eden in 24:5-6, Numbers 24:7-9 unites the blessing of Abraham with the promise of a king from Judah, and Adam's royal status might be a relevant precursor for the model of kingship in view.

In Balaam's final oracle, following the Edenic overtones in 24:5-6 and the announcements of the blessing of Abraham that the king will bring in Numbers 24:7-9, there seems to be an allusion to Genesis 3:15 in Numbers 24:17.33 The text reads,

I see him but not now;

I behold him but not near.

A star shall go forth from Jacob, and a sceptre shall arise from Israel, and he shall crush the forehead of Moab, and tear down all the sons of Seth (Num. 24:17).

The reference to a 'sceptre' points back to the sceptre that will not depart from Judah in Genesis 49:10 (שָׁבְט is used in both texts). Levine notes that the verb קור in the statement that the 'sceptre shall arise' is used in other texts to 'connote ascension to political leadership'. ${ }^{34}$ The phrase 'he shall crush the forehead of Moab' in Numbers 24:17 uses a

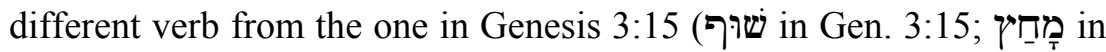
Num. 24:17), but we have learned that the themes of biblical theology are broader than individual words. The verb used in Genesis 3:15, שטר?, is rare in the OT, and its use elsewhere does not appear to echo the promise that the seed of the woman would crush the head of the serpent. ${ }^{35}$ But the verb in Numbers 24:17, allude in various ways to Genesis 3:15 (see Judg. 5:26; 2 Sam. 22:39; Hab. 3:13; Ps. 18:39[38]; 68:22[21], 24[23]; 110:5, 6; Job 26:12). ${ }^{36}$ In the context of Numbers 24, Moab is the nation over which Balak is king (22:4), and it is his desire to have Israel cursed (22:6). Under-

33 Dempster, Dominion and Dynasty, 116-17; Sailhamer, 'Creation, Genesis 1-11, and the Canon', 93, 98.

34 B. A. Levine, Numbers 21-36 (New York: Doubleday, 2000): 200, citing Judg. 5:7; $2 \mathrm{Kgs} 23: 25$, and offering the translation, 'A sovereign rises to power from Israel'.

35 The term is used in Ps. 139:11 ('surely the darkness will crush me') and Job 9:17 ('he will crush me with the tempest').

36 So also Sailhamer, 'Creation, Genesis 1-11, and the Canon,' 98-99 n. 41. Levine (Numbers 21-36, 201-02) writes, 'Once again, the verb $m-h-s$ "to strike, smash" (see above, in Notes to Num. 24:8) describes the death blow of the conquering warrior.' 
standing Israel's enemy, Moab, as the seed of the serpent, ${ }^{37}$ the statement that the ruler of Israel will crush the forehead of Moab can be understood as a poetic reformulation of the statement that the seed of the woman will crush the head of the seed of the serpent.

The Balaam oracles in Numbers 24, then, knit together these significant strands of promise. The blessing of Abraham is firmly linked to the king from Judah as the language of Genesis 49:9 is set next to the language of 27:29 and 12:3 in Numbers 24:9. The sceptre of the ruler from Judah mentioned in Genesis 49:10 is then set next to what appears to be an allusion to Genesis 3:15 in Numbers 24:17. Thus, it seems valid to conclude that these texts indicate that the fulfilment of the promises to Abraham would be realised through a triumphant king of Israel, descended from Judah, who would defeat Israel's enemies. These enemies of Israel are regarded as the seed of the serpent, so that their defeat is simultaneously Israel's victory. Israel's victory is God's victory.

We see a king from Judah arise over Israel in Samuel. In the highly significant narrative in 2 Samuel 7 there are faint allusions to Eden along with definite resonations of the promises to Abraham.

How might Eden be invoked in 2 Samuel 7? The chapter opens with a reference to the 'rest' that YHWH has given to Israel, and this rest apparently prompts David's desire to build a temple for YHWH. Building on the work of Levenson, Fishbane, and Blenkinsopp, Beale has explained the significance of the concept of rest in connection to sanctuaries, a rest that was enjoyed by God at the completion of his creation. ${ }^{38}$ Beale writes, 'God's rest both at the conclusion of creation in Genesis 1-2 and later in Israel's temple indicates not mere inactivity but that he had demonstrated his sovereignty over the forces of chaos

37 On the identity of the 'seed of the serpent and the seed of the woman' in Gen. 3:15, Tremper Longman (How to Read Genesis, 112-13) writes, 'As biblical history unfolds, we soon see that humankind is split into two groups, the godly and the ungodly. Indeed, we will see this split in the stories that follow in Genesis 4-11 as well as in the genealogies that include Cain and Seth, one notably evil and the other following God... . Throughout the Bible conflict erupts between these two groups.' Longman suggests that Augustine also saw Gen. 3:15 resulting in this division of humanity into two groups, and expressed it through his description of the City of God and the City of Man (Tremper Longman, How to Read Genesis, 123; and cf. 167).

38 The authors Beale cites observe the similarity of language used in the accounts of the creation of the cosmos and the building of the temple. 'Just as God rested on the seventh day from his work of creation, so when the creation of the tabernacle and, especially, the temple are finished, God takes up a "resting place" therein' (Beale, Temple, 61). 
(e.g. the enemies of Israel) and now has assumed a position of kingly rest further revealing his sovereign power.' ${ }^{39}$ Humanity ceased to participate fully in God's rest when God cursed the ground, and in the naming of Noah, with the explanation of his name, ${ }^{40}$ we see a longing for the lost rest. Deuteronomy points to a day when the people will enjoy rest in God's new sanctuary in the land he promised them (12:1011). Once the conquest is complete under Joshua, the land has rest from war (Josh. 11:13). A number of judges also bring salvation to Israel and give the land rest (Judg. 3:11, 30; 5:31; 8:28).

It seems significant, then, that in 2 Samuel 7:1, once 'YHWH had caused rest for him from all his surrounding enemies,' David's immediate desire is to build a temple for YHWH. The temple building impulse seems to reflect a desire to establish the presence of God among the people of Israel, to recapture a glimmer of Eden's glory. This point depends, of course, upon the validity of the connection that scholars such as Wenham, Walton, Averbeck, and Beale have made between Eden, the Tabernacle, and the Temple. ${ }^{41}$ There is a verbal connection to Edenic conditions in 2 Samuel 7:7, where God describes himself as 'walking among all the sons of Israel'. This verb, הָלרד, in the hithpael, appears in other significant statements of God walking among his people: in the Garden (Gen. 3:8) and in Israel's camp (Lev. 26:12; Deut. 23:15[14]). In these descriptions of Israel's rest from all her enemies, and in the allusion to God 'walking among' his people, we hear faint echoes of Eden. These echoes of Genesis 2-3 are no doubt refracted through other texts, ${ }^{42}$ but Eden is among, and perhaps the source of, the reverberations. This might be an instance of what Hays calls metalepsis, where 'one text alludes to an earlier text in a way that evokes resonances of the earlier text beyond those explicitly cited. The result is that the interpretation of a metalepsis requires the reader to recover unstated or suppressed correspondences between the two texts. ${ }^{43}$

39 Beale, Temple, 62; cf. 60-66.

40 Gen. 5:29, cf. Noah's name, נפ, with the word for rest, In Gen. 5:29 there is a play on Noah's name with the word נחם, 'comfort'.

41 Wenham, 'Sanctuary Symbolism in the Garden of Eden Story' in I Studied Inscriptions from before the Flood; J. H. Walton, 'Creation', in DOTP, 155-68, esp. 161, 165; 'Eden, Garden of', in DOTP, 202-207; 'Flood', in DOTP, 315-26, esp. 31617; R. E. Averbeck, 'Tabernacle', in DOTP, 807-27, esp. 816-18; Beale, Temple.

42 I have in mind the ones mentioned in this discussion.

43 The line preceding this explanation reads, 'In Echoes of Scripture in the Letters of Paul I sought to show that Paul's OT allusions and echoes frequently exemplify the 
In YHWH's response to David's desire to build a temple, the blessing of Abraham appears to be transmitted to David in the words of 2 Samuel 7:9, 'And I will make for you a great name, as the name of the great ones who were in the land'. In similar terms God had promised to Abraham, 'I will make your name great' (Gen. 12:2, forms of are employed in both texts). ${ }^{44}$ The comparative phrase, 'as the name of the great ones who were in the land' in 2 Samuel 7:9 could be a reference to Israel's patriarchs, whose names are made great through the record of what they did in Israel's Scriptures.

Yet another point of contact between Abraham and David is found in 2 Samuel 7:12, where we read, 'I will raise up your seed after you, who will come from your body, and I will establish his kingdom'. The words 'who will come from your body' reflect the statement made in Genesis 15:4, when Abram is told that Eliezer of Damascus would not be his heir, but one 'who will come from your body, he will be your heir'. The phrase used in both texts, 'who will come from your body

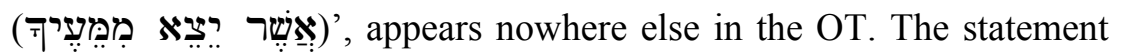
in 2 Samuel 7:12 that God will establish the kingdom of David's seed reminds us again of Adam's regal status (Gen. 1:26-28), the promise to Abraham that kings would come from him (17:6), the blessing of Judah (Gen. 49:9-12), and the Balaam oracle (Num. 24:17).

Finally, it is perhaps not insignificant that YHWH tells David, 'I will raise up your seed after you' (2 Sam. 7:12). This seed of David will be, according to the genealogy in Ruth 4:18-22, descended from Perez, Judah's son (Gen. 38:29). ${ }^{45}$ Thus the seed of David is seed of Judah, seed of Abraham, and the genealogies in Genesis 5 and 11 show us that he is also seed of the woman. ${ }^{46}$

literary trope of metalepsis' (R. B. Hays, The Conversion of the Imagination [Grand Rapids: Eerdmans, 2005]: 2).

44 R. F. Youngblood (1, 2 Samuel [Grand Rapids: Zondervan, 1992]: 888) writes, 'The divine promise to make the name of David great is a clear echo of the Abrahamic covenant (cf. Gen. 12:2).'

45 For an elegant treatment of Gen. 38, see Jacob of Serugh's [c. 450-521] 'Verse Homily on Tamar' in S. Brock, 'Jacob of Serugh's Verse Homily on Tamar (Gen. 38)', Le Muséon 115 (2002): 279-315. I thank Tim Edwards for pointing me to this piece.

46 The enigmatic phrase at the end of 2 Sam. 7:19 might also be illumined by the pos-

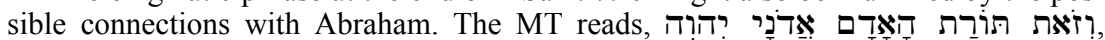
which might be literally rendered, "And this is the Torah of the Man, my Lord YHWH!' Is David depicted here connecting what YHWH has said to him to the promised seed of the woman? There is no consensus on how the phrase should be

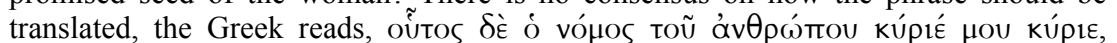
which could be rendered literally just as I have rendered the Hebrew above (replacing 
From these observations it would seem that the narratives in both Genesis $1-11$ and 12 and following inform 2 Samuel 7. Similar influences can be felt in Psalm 72.

Before looking at Psalm 72, however, I want to observe that if I am correct, the promises to Abraham, which answer the curses following Adam's sin, are passed on to David. Given the national aspect of the promise to Abraham (Gen. 12:2, 'great nation'), and the promise of royal descendants (17:6), the promises to Abraham might be seen as preparing the way for David's rise to the throne. In fact, viewing the matter from a different perspective, Wifall alludes to 'parallels between the so-called "Davidic covenant" (2 Sam. 7) and the Yahwist's portrait of Israel's pre-history in Gen[esis]. ${ }^{\prime 7}$ If the phrase 'messianic expectation' is 'used to refer to expectations focusing on a future royal figure sent by God who will bring salvation to God's people and the world and establish a kingdom characterised by features such as peace and justice, ${ }^{48}$ and if the promises to Abraham are reaffirmed to David, perhaps it is not out of place to suggest that the promises to Abraham figure into messianic expectation. When Solomon followed David as the anointed king of Israel, he became, in a sense, the Messiah, which brings us to Psalm 72 .

The superscription of Psalm 72 is, 'Of Solomon (לִ:שְלמה), but the Psalm closes with the note that 'The prayers of David, the son of Jesse, are ended' (72:20). This has prompted the suggestion that perhaps this was David's death-bed prayer for Solomon. ${ }^{49}$ In this discussion I am mainly interested in highlighting the way Psalm 72 seems to link the curse on the serpent and his seed to the blessing of Abraham. Further, the crushing of the seed of the serpent and the realisation of the blessing of the nations is brought about through the son of David, the messianic king of Israel.

The fertility described in Psalm 72:3 is remarkable, perhaps even Edenic, and then verse 4 reads, 'May he judge the poor of the people,

\footnotetext{
'Torah' with 'law'). If the ESV's rendering is correct, 'and this is instruction for mankind, O Lord GoD!' we might conclude that David is making a connection with the blessing for all the nations promised to Abraham (Gen. 12:3). If the phrase is taken as a question, 'Is this your usual way of dealing with man, O Sovereign Lord?' (NIV, similarly AV, NASB, NET), it becomes difficult to see a connection to either Genesis 3 or 12 .

47 W. Wifall, 'Gen 3:15-A Protoevangelium?', $C B Q 36$ (1974): 362.

48 W. H. Rose, 'Messiah', in DOTP, 566.

49 Cf. W. A. VanGemeren, Psalms (Grand Rapids: Zondervan, 1991): 470.
} 


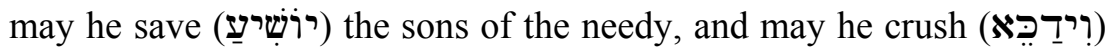
the oppressor!' The salvation of the needy is side by side with the crushing of the oppressors. The verb used in Psalm 72:4, דָדָ, is not the verb used in Genesis 3:15, but it is used in Psalm 89:11[10], where we read, 'You crushed Rahab like one who is slain, by the arm of your might you scattered your enemies.' Rahab is elsewhere identified with Leviathan (Ps. 74:14) 50 $^{5}$ and the dragon (Isa. 51:9). If Rahab is a crushed serpent, an allusion to Genesis 3:15 seems plausible. If the enemies of Israel are indeed regarded as the seed of the serpent, then when they are crushed the ancient judgement on the snake and his offspring finds fulfilment. The impression that the victory of the Davidic king is being described in terms of Genesis 3 is strengthened when we read in Psalm 72:9, 'May his enemies lick the dust!' This matches the curse on the serpent that dust would be his food (Gen. $3: 14)$. Thus, by calling for YHWH to cause the enemies of the seed of the woman to lick the dust, the Psalmist is calling on him to carry out the judgement expressed in Genesis 3. The reference to crushed foes who have dust in their mouths seems to allude to Genesis $3: 14-15 .{ }^{51}$

Near the end of the Psalm, this triumphant Davidic king is blessed in terms that recall Genesis 12:2-3: 'May his name endure forever $\ldots$ and may they be blessed in him, may all nations call him blessed!' (Ps. 72:17). The statement, 'may they be blessed in him' in Psalm 72:17 echoes Genesis 12:3, 'and all the families of the earth will be blessed in you'. The concluding statement in Psalm 72:17, 'may all nations call him blessed', employs different language but is synonymous with the statement in Genesis 12:2 that speaks of those who bless Abram. And finally, the great name promised to Abram in Genesis 12:2 is reformulated in Psalm 72:17 as a name that will endure forever. Psalm 72 , then, seems to interpret the crushing of the serpent's head as a blessing that the messianic warrior king of Israel will bring in fulfilment of the promises to Abraham.

50 M. Dahood (Psalms II: 51-100 [Garden City: Doubleday, 1968]: 314) identifies Rahab as 'A mythological monster representing the restless waters of the ocean. In Ps. lxxiv 14 he is called Leviathan.'

51 Wifall ('Gen. 3:15', 363) also sees allusions to Gen. 3:15 in Ps. 72:9 and 89:11. 


\section{The Blessings of Abraham in Messiah Jesus}

When we turn to the New Testament, we find that the blessing of Abraham is interpreted as something brought about by the Davidic Messiah, Jesus, in at least three places. As Luke recounts Mary's rejoicing in God, she refers to what God spoke 'to our fathers, to Abraham and to his seed forever' in Luke 1:55. Then as Zacharias prophesies at the birth of his son, John, he indicates - filled by the Holy Spirit as he is (1:67) - that the seed of David will bring in the blessing of Abraham. We read in Luke 1:68-75:

68a Blessed be the Lord God of Israel,

$68 \mathrm{~b}$ because he has visited and made redemption for his people,

69 and he raised up a horn of salvation for us in the house of his servant David,

70 just as he spoke through the mouth of his holy prophets from of old, 71 salvation from our enemies and from the hand of those who hate us, 72a to deal mercifully with our fathers

$72 \mathrm{~b}$ and to remember his holy covenant,

73a the oath which he swore to Abraham our Father,

$73 \mathrm{~b}$ to grant to us, having been delivered from the hand of our enemies, to serve

74-75 him fearlessly in holiness and righteousness before him all our days.

For the purposes of this study, the key features of this text are in verses $69-70$ and $72-73$. Verse 69 states that the salvation in view is going to be brought by a 'horn' from the house of David, referring to a Davidic warrior who will save his people. Verse 70 makes plain that the salvation, and the messianic warrior who brings it, have been described by Israel's prophets in her Scriptures. Verse 72 links the salvation that the Davidic messiah brings to the covenant with the fathers, and then verse 73 explains that this covenant was sworn to Abraham. It would seem that Luke intends for his readers to understand that God will make good on his promise to Abraham by accomplishing salvation for Israel through the Davidic king, and his gospel presents Jesus as that messianic warrior king.

Luke returns to the idea that Jesus is the fulfilment of the promise in Genesis 12:3 in Acts 3:25. There Luke depicts Peter preaching in Jerusalem to his Jewish contemporaries that 'all the prophets from Samuel and those who followed him, as many as have spoken have proclaimed these days. You are the sons of the prophets and of the covenant, which 
God established with your fathers saying to Abraham, "And in your seed all the families of the earth will be blessed"' (Acts 3:24-25).

Paul also interprets what has taken place in Jesus as the fulfilment of the promise to Abraham given in Genesis 12:3. He writes in Galatians $3: 8$, 'But the Scripture, having foreseen that God would justify the nations from faith, preached the gospel beforehand to Abraham that "all the nations will be blessed in you." Paul returns to this idea in 3:14, making the connection between Jesus and the promise to Abraham explicit with the words, "in order that the blessing of Abraham might come to the nations in Messiah Jesus, in order that we might receive the promise through faith.' It would seem, then, that Luke and Paul interpreted the promise to Abraham in Genesis 12:3 that all nations of the earth would be blessed in him as being fulfilled in Jesus.

Jesus is presented in the NT as the seed of Abraham who brings the blessing of Abraham to the Gentiles, but is he presented as the seed of the woman who crushes the serpent's head? In Luke 10:18 Jesus is depicted reporting that he saw Satan fall from heaven, and in the next verse he grants his disciples authority to tread on serpents and scorpions (10:19). The dragon who seeks to kill the male child of the woman in Revelation 12 is one place in the NT where Jesus is presented as the seed of the woman in conflict with the serpent. The statement in Revelation 12:5 that the male child 'will shepherd all the nations with an iron rod' establishes that this child is Messiah Jesus. The many statements in the NT that the enemies of Jesus will be placed under his feet might also reflect imagery from Genesis 3:15 through the lens of Psalm 110 (Matt. 22:44 and parallels; Acts 2:35; 1 Cor. 15:25; Eph. 1:20-22; Heb. 2:5-9, 14-15; 10:13).

\section{Conclusion}

Adam and Eve were expelled from God's presence when they transgressed his command. Their action brought a curse on the one who tempted them and resulted in their appointed roles being made more difficult. The blessing of Abraham promised seed, land, and blessing. The promise of seed overcomes the cursed difficulty of childbearing and the loss of harmony between the man and the woman. The promise of land hints at a place where God will once again dwell with his people. The promise of blessing heralds the triumph of the seed of the 
woman over the seed of the serpent. The blessing is not only for Israel, but for all the families of the earth. These promises fed the hopes, the eschatological hopes, of those who followed in the footsteps of the faith of Abraham, those who considered themselves seed of the woman. The sustenance of these hopes seems to have been the reason the accounts were recorded and passed down, ${ }^{52}$ as those who believed God's promises held to the faith that he would make good on his word. All the promises of God are yes and amen in Jesus the Messiah (2 Cor. 1:20), who lives and reigns with the Father and the Holy Spirit, ever one God, world without end. Amen.

52 See further John H. Sailhamer, "The Messiah and the Hebrew Bible," JETS 44 (2001): 23 